\title{
Comparison of the non-mortal gunshot and handmade explosive blast traumas during a low-intensity conflict on urban terrain
}

Hikmet Erhan Güven', Sedat Bilge ${ }^{2}$, Ali Attila Aydın², Mehmet Eryılmaz'

\section{ABSTRACT}

Cite this paper as:

Güven HE, Bilge S, Aydın AA, Erylmaz M. Comparison of the non-mortal gunshot and HE blast traumas during a low-intensity conflict on urban terrain. Turk J Surg $201834(3): 221-224$

'Department of General Surgery, Health Sciences University, Gülhane Training and Research Hospital, Ankara, Turkey

${ }^{2}$ Department of Emergency Medicine, Health Sciences University, Gülhane Training and Research Hospital, Ankara, Turkey

This study was presented at the $11^{\text {th }}$ National Trauma and Emergency Surgery Congress 5-9 April 2017, Antalya, Türkiye.

\section{Corresponding Author} Hikmet Erhan Güven e-mail: drerhanguven@gmail.com

Received: 18.04 .2017 Accepted: 17.09.2017

Available Online Date: 31.08.2018

CCopyright 2018 by Turkish Surgical Association

Available online at

www.turkjsurg.com
Objectives: We aimed to conduct a cross-sectional data analysis involving 60 patients wounded during a lowintensity conflict on urban terrain.

Material and Methods: Data of the 60 patients wounded during a low-intensity conflict on urban terrain between September $1^{\text {st }}, 2016$, and January 15th, 2017, and transferred to our hospital after the initial medical interventions conducted in the regional hospitals were probed retrospectively. Group A consisted of 25 (41.67\%) patients suffering gunshot wounds, and Group B consisted of 35 (58.33\%) patients with blast trauma injuries. Their Abbreviated Injury Scale scores were compared according to the injured body compartment.

Results: In both groups, extremities were the most common site of injury (17 [50\%] for Group A, 18 [33.33\%] for Group B). The difference between the two groups was statistically significant for only head and neck injuries and facial injuries $(p<0.05)$. In each group, only one body compartment was affected in 19 patients, which represented $55.88 \%$ of patients in Group A and 35.18\% of patients in Group B. Injuries of three compartments concurrently occurred in $3(8.82 \%)$ patients in Group A and 4 (7.4\%) patients in Group B. None of our patients died because of their injuries.

Conclusion: Contrary to the expected, gunshot casualties were found to be more likely to suffer from extremity injuries than blast casualties did, and it should be noted that blast trauma casualties tend to have multiple compartment injuries that should not be missed. Ocular ruptures are also common, especially with blast injuries, warranting equipping the personnel with protective goggles.

Keywords: AIS, blast trauma injury, gunshot injury, urban terrain

\section{INTRODUCTION}

Early post-World War periods are known to change medical approaches to the injured patient suffering from trauma. Today, modern warfare is likely to take place, not in the fields, but on the urban terrain where once peaceful neighborhoods become battlefields. Combats of this kind made a paradigm shift in treatment approaches for high-kinetic-energy (HKE) injuries. The prime reason for this shift is the change in injury patterns. HKE injuries differ by means of affected body compartment according to its cause: bullets (B) or fragmented parts of handmade explosives (HE). Especially HE, which are widely used by terrorists, are known to cause complex and unpredictable damages $(1,2)$. In this study, we aimed to analyze the Abbreviated Injury Scale (AIS) compartments of patients who were affected by the B or HE traumas to reveal the anatomic locations which the protective measures should be directed at (3).

\section{MATERIAL AND METHODS}

This retrospective cross-sectional study is designed to examine the data of patients affected by the HKE injuries between September $1^{\text {st }}, 2016$ and January $15^{\text {th }}, 2017$, who were referred to our institution after their first medical intervention took place in the regional hospitals of the southeast region of our country. All patients were wounded in a low-intensity conflict on urbanized terrain (LICUT) during our national fight against terrorism and transferred to our center for further treatment after which they were considered to be medically stable. Patients were sorted according to their age, gender, the type of HKE trauma cause, and affected anatomical compartment. They were reclassified as Group A and Group B according to the cause of the HKE injury as B and HE explosives. The sites of penetration frequencies were determined using the AIS compartments for each group. Distribution of injured organs/tissues was also analyzed in the two groups. The SPSS for Windows version 22.0 (Statistical Software, Chicago, IL, USA) was used for statistical analysis, and chi-squared and Fisher's exact test were applied for data comparison. A p-value of $<0.05$ was considered to be statistically significant.

This study was performed in compliance with the Declaration of Helsinki.

\section{RESULTS}

All 60 patients were male with a mean age of 31 (23-57). Twenty-five (41.67\%) patients injured by gunshot wounds were grouped as Group A, and 35 with blast injuries were grouped as Group B. 
Two groups were compared according to their sites of injury according to AIS compartments (Table 1). The extremities were the most common compartment affected by trauma in 17 (50\%) patients in Group A, and in 18 (33.33\%) patients in Group B. Head and neck and facial injuries were significantly more common in Group B ( $p<0.05)$. Other compartment injuries showed no significant difference according to the type of the HKE trauma.

In each group, only one body compartment was wounded in 19 patients, which represented $76 \%$ of patients in Group A and $54.28 \%$ of patients in Group B. Two compartments were injured in 3 (12\%) patients in Group A and 12 (34.29\%) patients in Group B. Injuries in three compartments concurrently occurred in 3 (12\%) patients in Group A and 4 (11.43\%) patients in Group B. None of the wounded patients had 4 or more body parts affected.

In addition to compartments, anatomic injury sites were also analyzed according to the type of the HKE trauma (Table 2). Patients wounded by HE mostly suffered tibia fractures on the left side $(n=3)$ and ulna fractures on the right side $(n=3)$. The nerve damage and vascular injuries were the same for both sides, and the ocular globe rupture, which was only seen in patients in Group B, was the most common organ injury $(n=9$, 5 on the left, 4 on the right). The most frequently injured solid organs were the spleen $(n=4)$ and liver $(n=4)$. . Penetration of foreign bodies was mostly encountered in extremities $(n=5)$ followed by eyeballs and the thoracic wall, and the secondand third-degree burns were mostly seen in the left upper extremities $(n=2)$.

Gunshot wounds caused by bullets were common in extremities, mostly in the left humerus $(n=3)$. Neurovascular injuries and amputations were same for both sides. Grade I-II splenic trauma was the most common type of solid organ injury. When the two types of injuries were compared according to the incidence of the organ/tissue injury, HE caused the fractures of the humerus, ulna, femur, and tibia (open), and gunshots caused the fractures of the humerus and tibia. Neurovascular injuries, amputation, and spinal cord injury rates did not differ among the two groups. In patients suffering blast traumas, the liver and spleen injuries were common, followed by eyeball ruptures and trapped foreign bodies on the anterior chest wall.

Although the mortality rate was $0 \%$ among our patients, 9 enucleations, 4 amputations, 7 splenectomies, and 7 colonic resections were performed by means of organ losses, all more common with blast injuries ( $n=21$ vs. $n=6$ ).

\section{DISCUSSION}

It has been known that injuries caused by HKE are the most common cause of death among trauma patients (4). As HE is being used more frequently during LICUTs, blast injuries caused by them bring new challenges as well as contributing to the development of new treatment approaches (1). Furthermore, as Hoencamp et al. (5) reported, the frequency of blast injuries is $85 \%$ greater now than during the former combats and wars.

In this study, we aimed to analyze patients wounded during LICUTs and referred to our hospital after their initial resuscitative stabilization have been ensured at field hospitals. Wound patterns are investigated according to the cause of the HKE trauma: bullets or HE. Ever-changing and technologically improving pistols and rifles versus HE made from the everyday materials are also compared for their destructive effects.

Dubost et al. (6) reported their experience as the Seventh French Forward Surgical Team during military operations in Mali and the Central African Republic and concluded that gunshot wounds were the most common type of injury during their campaign. In our series, most of our patients were injured by $\mathrm{HE}$, which clearly are a product of the tactical nature and reality of LICUT. A methodical review by Hoencamp et al. (7) revealed that $72 \%$ of combat injuries are due to blast traumas. In our study, $58.33 \%$ patients suffered from a blast trauma.

Abbreviated Injury Scale is one the most commonly used and well-defined trauma scoring systems that relies on objective findings according to the anatomic site of the injury (compartment) $(3,8)$. This severity scoring system provides important information that guides the treatment, helps to anticipate the outcomes, and is also handy for standardizing data when structuring retrospective analyses (8). Since patients were medically stabilized in the field hospitals prior to their transfer our hospital, the mortality rate was $0 \%$. Thus, the Injury Severity Score was not applicable since we couldn't gather the initial data of the patients, so the AIS compartments incidence analyses are done. The AIS scores are reported to be indeterminable in some cases (9). The AIS scores of injured compartments were probably low, but not well-defined enough to give a quantitative value to our patients. Therefore, we grounded our study on compartments rather than AIS scores and aimed to interpret whether a flak jacket or similar protective garment had any relation to the site of injury.

With regard to the injured compartments according to the type of trauma, extremities were affected in $50 \%$, the abdomen in $20 \%$, and thorax in $20 \%$ of the patients with bullet

\section{Table 1. Distribution of injuries according to their compartments}

\begin{tabular}{|c|c|c|c|c|c|c|c|c|c|}
\hline & & & Head and neck & Face & Thorax & Abdomen & Extremity & External & Total Compartments Involved \\
\hline \multirow[t]{2}{*}{ Gunshot n (\%) } & $25(41.67)$ & $\mathrm{n}$ & 3 & 1 & 6 & 6 & 17 & 1 & 34 \\
\hline & & $\%$ & 8.8 & 2.9 & 17.6 & 17.6 & 50 & 2.9 & 100 \\
\hline \multirow[t]{2}{*}{ Blast n (\%) } & $35(58.33)$ & $\mathrm{n}$ & 6 & 13 & 8 & 8 & 18 & 1 & 54 \\
\hline & & $\%$ & 11.1 & 24 & 14.8 & 14.8 & 33.3 & 1.8 & 100 \\
\hline \multirow[t]{2}{*}{ Total n (\%) } & $60(100)$ & $\mathrm{n}$ & 9 & 14 & 14 & 14 & 35 & 2 & 88 \\
\hline & & $\%$ & 10.2 & 15.9 & 15.9 & 15.9 & 39.7 & 2.27 & 100 \\
\hline
\end{tabular}


injuries. Blast traumas have caused damage to the extremities in $39.77 \%$ and to the face in $24.08 \%$ of the wounded. It is known that gunshot assaults, especially sniper attacks target deadly compartments. It should be stated that our analysis does not include lethal traumas, therefore extremity injuries made up the majority of cases with the gunshot trauma. Perhaps flak jackets provided a degree of protection against bullets, as mentioned in other studies so that the thoracoabdominal injuries were ranked after the extremity injuries (10). When considered together, nonfatal injuries caused by either gunshots or blast trauma are found to affect extremities in our series.
When the number of compartments involved is examined in both types of injuries, the caused damage was mostly confined in only one compartment (76\% for gunshot injuries and $54.28 \%$ for blast traumas), and no more than three compartments were involved in either group. This could be explained by patients having more than three compartments injured who either lost their lives on the field or were not suitable for transfer.

The most commonly affected organ/tissue by both gunshot and blast traumas were extremities, as previous studies have reported $(6,7)$. Therefore, amputations due to neurovascular

Table 2. Injured organ/tissue incidence

\begin{tabular}{|c|c|c|c|c|c|c|}
\hline \multirow{3}{*}{$\begin{array}{l}\text { Damaged } \\
\text { Organ/ } \\
\text { Tissue }\end{array}$} & \multicolumn{6}{|c|}{ Patients } \\
\hline & \multicolumn{3}{|c|}{ Blast } & \multicolumn{3}{|c|}{ Bullet } \\
\hline & Left & Right & Total & Left & Right & Tota \\
\hline & \multicolumn{6}{|c|}{ Extremity Damage - Fractures } \\
\hline Humerus & 1 & 2 & 3 & 3 & 2 & 5 \\
\hline Tibia & 3 & 2 & 5 & 2 & 1 & 3 \\
\hline Fibula & 0 & 0 & 0 & 1 & 0 & 1 \\
\hline Scapula & 0 & 1 & 1 & 1 & 0 & 1 \\
\hline Talus & 0 & 0 & 0 & 1 & 0 & 1 \\
\hline Calcaneus & 1 & 0 & 1 & 1 & 0 & 1 \\
\hline Metacarpus & 1 & 0 & 1 & 0 & 0 & 0 \\
\hline Maxilla & 1 & 0 & 1 & 0 & 0 & 0 \\
\hline Metatarsus & 1 & 0 & 1 & 1 & 0 & 1 \\
\hline Clavicula & 0 & 0 & 0 & 0 & 1 & 1 \\
\hline Iliac Wing & 1 & 2 & 3 & 0 & 0 & 0 \\
\hline Radius & 1 & 0 & 1 & 0 & 0 & 0 \\
\hline Ulna & 1 & 3 & 4 & 2 & 0 & 2 \\
\hline Shoulder & 1 & 0 & 1 & 0 & 0 & 0 \\
\hline Femur & 2 & 2 & 4 & 0 & 2 & 2 \\
\hline
\end{tabular}

Neurovascular Injuries - Amputations

$\begin{array}{lllllll}\text { Brachial Artery } & 0 & 0 & 0 & 0 & 1 & 1 \\ \begin{array}{l}\text { Axillary Artery } \\ \text { and Vein }\end{array} & 0 & 0 & 0 & 0 & 1 & 1 \\ \text { Renal Artery } & 1 & 0 & 1 & 0 & 0 & 0 \\ \text { Ulnar Artery } & 0 & 0 & 0 & 1 & 0 & 1 \\ \text { Ulnar Nerve } & 1 & 0 & 1 & 1 & 0 & 1 \\ \begin{array}{l}\text { Brachial Plexus } \\ \text { Damage }\end{array} & 0 & 0 & 0 & 1 & 0 & 1 \\ \begin{array}{l}\text { Above Elbow } \\ \text { Amputation }\end{array} & 0 & 0 & 0 & 0 & 1 & 1 \\ \begin{array}{l}\text { Below Knee } \\ \text { Amputation }\end{array} & 0 & 1 & 1 & 0 & 1 & 1 \\ \begin{array}{l}\text { Hand Finger } \\ \text { Amputation }\end{array} & 1 & 0 & 1 & 0 & 0 & 0\end{array}$

Spinal Cord Injuries

$\begin{array}{lllllll}\begin{array}{l}\text { Nondisplaced } \\ \text { C1 Fracture }\end{array} & 1 & 0 & 0 & 0 & 0 & 0 \\ \begin{array}{l}\text { Spinal Cord } \\ \text { Injury T12 }\end{array} & 0 & 1 & 0 & 0 & 0 & 0\end{array}$

\begin{tabular}{|c|c|c|c|c|c|c|}
\hline \multirow{3}{*}{$\begin{array}{l}\text { Damaged } \\
\text { Organ/ } \\
\text { Tissue }\end{array}$} & \multicolumn{6}{|c|}{ Patients } \\
\hline & \multicolumn{3}{|c|}{ Blast } & \multicolumn{3}{|c|}{ Bullet } \\
\hline & Left & Right & Total & Left & Right & Total \\
\hline $\begin{array}{l}\text { Spinal Cord } \\
\text { Injury L1 }\end{array}$ & 1 & 0 & 0 & 0 & 0 & 0 \\
\hline Brain & 3 & 2 & 0 & 0 & 0 & 0 \\
\hline Eyeball Rupture & 5 & 4 & 9 & 0 & 0 & 0 \\
\hline Pneumothorax & 1 & 1 & 2 & 0 & 2 & 2 \\
\hline Hemothorax & 1 & 1 & 2 & 0 & 0 & 0 \\
\hline Lung Contusion & 1 & 1 & 2 & 2 & 0 & 2 \\
\hline $\begin{array}{l}\text { Liver Laceration } \\
\text { (Grade I-II ) }\end{array}$ & 4 & 2 & 0 & 0 & 0 & 0 \\
\hline $\begin{array}{l}\text { Spleen } \\
\text { Laceration } \\
\text { ( Grade I-II ) }\end{array}$ & 4 & 3 & 0 & 0 & 0 & 0 \\
\hline Colon & 4 & 0 & 0 & 0 & 0 & 0 \\
\hline Rectum & 2 & 1 & 0 & 0 & 0 & 0 \\
\hline Renal Laceration & 2 & 1 & 0 & 0 & 0 & 0 \\
\hline Bladder & 0 & 1 & 0 & 0 & 0 & 0 \\
\hline Urethra & 2 & 1 & 0 & 0 & 0 & 0 \\
\hline $\begin{array}{l}\text { Rupture of } \\
\text { Lateral } \\
\text { Collateral } \\
\text { Ligament }\end{array}$ & 0 & 0 & 0 & 0 & 1 & 1 \\
\hline $\begin{array}{l}\text { Rupture of } \\
\text { Collateral } \\
\text { Knee } \\
\text { Ligament }\end{array}$ & 1 & 1 & 2 & 0 & 0 & 0 \\
\hline
\end{tabular}

\section{Foreign Body Localization}

$\begin{array}{lcccccc}\text { Extremity } & 3 & 2 & 5 & 0 & 0 & 0 \\ \text { Rectum } & 1 & 0 & 0 & 0 & 0 & 0 \\ \text { Eyeball } & 2 & 2 & 4 & 0 & 1 & 1 \\ \text { Abdomen } & 1 & 0 & 0 & 0 & 0 & 0 \\ \text { Thorax } & 4 & 0 & 0 & 0 & 0 & 0 \\ \text { Neck } & 1 & 0 & 0 & 0 & 0 & 0 \\ \text { Mandibula } & 2 & 0 & 0 & 0 & 0 & 0 \\ & & & 2^{\circ} \text { and } 3^{\circ} \text { Burns } & & 0 \\ \text { Shoulder } & 0 & 1 & 1 & 0 & 0 & 0 \\ \text { Back } & 1 & 0 & 0 & 0 & 0 & 0 \\ \text { Upper Extremity } & 2 & 0 & 2 & 0 & 0 & 0\end{array}$


injuries of the extremities were commonly encountered. The injuries causing brain damage were similar in both groups. However penetrating injuries were more common in gunshot traumas. This finding could only be interpreted if the data of mortal injuries were available.

We found that eyeball ruptures are common in blast injuries ( $n=9,25.71 \%$ of blast injuries). When all wounded patients during LICUTs are considered, eyeball ruptures were present in $15 \%$, which warrants the idea of wearing eye protecting goggles during LICUTs.

Solid organ injuries such as liver and spleen are more common among blast injury victims even when flak jackets are worn (10). This is because of fragmentation of shrapnel-like items such as nails, iron fragments, and screws embedded in HEs, as well as blunt trauma caused by the pressure.

Shacfor et al. (11) reported in their multicenter study that both gunshot and blast injuries tend to be mortal. Since our hospital played a referral center role in this particular situation, we had no mortalities. This allowed us to make a cross-sectional analysis of non-mortal gunshot and blast injury victims by means of their injury types and injured compartments.

Not having a standardized national database of trauma patients in Turkey is the main limitation of this study.

\section{CONCLUSION}

Although injury scores according to the AIS system could not be obtained, our cross-sectional study still provides useful information for the new era of modern warfare.

As a result, regardless of the injury type (gunshot or blast), non-mortal victims of LICUTs are likely to suffer from extremity wounds and especially blast injuries caused by $\mathrm{HE}$, which tend to affect more than one compartment of the body, including a high incidence of eyeball ruptures. Every effort should be made to assess victims of blast trauma injuries not to miss any possible affected body compartment. Our series that was small in number also suggests that personnel facing low-intensity warfare like LICUTs or military operations on urban terrain should be equipped with protective goggles as well as flak jackets.

Ethics Committee Approval: Authors declared that the research was conducted according to the principles of the World Medical Association Declaration of Helsinki "Ethical Principles for Medical Research Involving Human Subjects" (amended in October 2013).

Informed Consent: Informed consent was not received due to the retrospective nature of the study.
Peer-review: Externally peer-reviewed.

Author Contributions: Concept - H.E.G., S.B., A.A.A., M.E.; Design - M.E., H.E.G., S.B., A.A.A.; Supervision - M.E., H.E.G., A.A.A., S.B.; Resource - H.E.G., S.B., A.A.A., M.E.; Materials - A.A.A., S.B., H.E.G.; Data Collection and/or Processing - A.A.A., S.B., H.E.G., M.E.; Analysis and/ or Interpretation - M.E., A.A.A., H.E.G., S.B.; Literature Search - H.E.G., M.E.; Writing Manuscript - H.E.G., M.E.; Critical Reviews - H.E.G., S.B., A.A.A, M.E.

Conflict of Interest: The authors have no conflicts of interest to declare.

Financial Disclosure: The authors declared that this study has received no financial support.

\section{References}

1. Champion HR, Holcomb JB, Young LA. Injuries from explosions: physics, biophsycics, pathology, and required research focus. Mil Med 2006; 171: 273-277.

2. Özer MT, Coşkun K, Öğünç Gl, Eryılmaz M, Yiğit T, Kozak O, et al. The disguised face of blast injuries: shock waves. Ulus Travma Acil Cerrahi Derg 2010; 16: 395-400.

3. JAMA: Rating the severity of tissue damage. The abbreviated scale. JAMA 1971; 215: 277-280. [CrossRef]

4. Walker JJ, Kelly JF, McCriskin BJ, Bader JO, Schoenfeld AJ. Combat-related gunshot wounds in the United States Military: 20002009 (Cohort Study). Int J Surg 2012; 10: 140-143. [CrossRef]

5. Hoencamp R, Huizinga EP, van Dongen TT, Idenburg FJ, Ramasamy $A$, Leenen $L P$, et al. Impact of explosive devices in modern armed conflicts: in-depth analysis of Dutch battle casualties in southern Afghanistan. World J Surg 2014; 38: 25512557. [CrossRef]

6. Dubost C, Goudard Y, Soucanye de LE, Contargyris C, Evans D, Pauleau G. Combat casualties from two current conflicts with the seventh French Forward Surgical Team in Mali and central African Republic in 2014. J. R. Army Med Corps 2016; 162: 450455. [CrossRef]

7. Hoencamp R, Vermetten E, Tan EC, Putter H, Leenen LP, Hamming JF. Systematic review of the prevalence and characteristics of battle casualties from NATO coalition forces in Iraq and Afghanistan. Injury 2014; 45: 1028-1034. [CrossRef]

8. Lawnick MM, Champion HR, Gennarelli T, Galarneau MR, D'Souza E, Vickers RR, et al. Combat injury coding: a review and reconfiguration. J Trauma Acute Care Surg 2013; 75: 573-581. [CrossRef]

9. Tohira H, Jacobs I, Mountain D, Gibson N, Yeo A. Systemic review of predictive performance of injury severity scoring tools. Scand J Trauma Resusc Emerg Med 2012; 20: 63. [CrossRef]

10. Tong D, Beirne R. Combat body armor and injuries to the head, face, and neck region: a systemic review. Mil Med 2013; 178: 421426. [CrossRef]

11. Shackford SR, Kahl JE, Calvo RY, Kozar RA, Haugen CE, Kaups KL, et al. Gunshot wounds and blast injuries to the face are associated with significant morbidity and mortality: results of an 11-year multi-institutional study of 720 patients. J Trauma Acute Care Surg 2014; 76: 347-352. [CrossRef] 